Research, part of a Special Feature on The Recent History and Practice of Local Fisheries in a Globalizing World

\title{
Historical Perspectives and Recent Trends in the Coastal Mozambican Fishery
}

Jessica L. Blythe $^{1}$ Grant Murray $^{2}$ and Mark S. Flaherty ${ }^{1}$

\begin{abstract}
Historical data describing changing social-ecological interactions in marine systems can help guide small-scale fisheries management efforts. Fisheries landings data are often the primary source for historical reconstructions of fisheries; however, we argue that reliance on data of a single type and/or from a single scale can lead to potentially misleading conclusions. For example, a narrow focus on aggregate landings statistics can mask processes and trends occurring at local scales, as well as the complex social changes that result from and precipitate marine ecosystem change. Moreover, in the case of many smallscale fisheries, landings statistics are often incomplete and/or inaccurate. We draw on case study research in Mozambique that combines national landings statistics and career history interviews with fish harvesters to generate a multi-scale historical reconstruction that describes social-ecological interactions within the coastal Mozambican fishery. At the national level, our analysis points toward trends of fishing intensification and decline in targeted species, and it highlights the significant impact of small-scale fisheries on marine stocks. At the local level, fishers are experiencing changes in fish abundance and distribution, as well as in their physical, social, and cultural environments, and have responded by increasing their fishing effort. We conclude with a discussion of the governance implications of our methodological approach and findings.
\end{abstract}

Key Words: fisheries management; fishers' knowledge; marine environmental history; Mozambique; small-scale fisheries

\section{INTRODUCTION}

Coastal ecosystems around the world are being restructured by overfishing and other factors (Jackson et al. 2001, Myers and Worm 2003). In response, fisheries managers and researchers are calling for more nuanced understandings of the complex historical interactions between fishers and marine systems (Murray et al. 2006, St. Martin et al. 2007). Developing effective fisheries governance and management responses requires an understanding of social-ecological transformations, including major trends and the suite of behaviors, rationales, and motivations that drive the interactions between fishers and their environments at different scales (Ludwig et al. 1993, Ommer 2007).

Landings data are often the primary source for historical reconstructions of fisheries (Pauly et al. 1998, Garcia and de Leiva Moreno 2003). When combined with macro-level historical information and analysis, they can be useful for interpreting macro-level social-ecological interactions. However, we argue that reliance on data of a single type and/ or from a single scale can lead to misleading conclusions. For example, a narrow focus on aggregate landings statistics can mask processes and trends occurring at local scales, as well as many of the complex social changes that both result from and create marine ecosystem change (Murray et al. 2007). Furthermore, in developing countries, landings data are often incomplete and underestimate total catch, particularly by the small-scale sector (Zeller et al. 2007, FAO 2011). The underrepresentation of small-scale fisheries in national landings is due to a variety of factors, including political marginalization linked to their relatively low contribution to gross domestic product and the cost associated with monitoring spatially diverse and often physically remote fisheries by resourcelimited governments (Béné 2003, Zeller et al. 2006, Jacquet et al. 2010). In Mozambique, for example, national catch data for the small-scale sector have been calculated using a sample of provinces that excluded the province with the largest number of active boats (Jacquet et al. 2010). In these cases, there is a need to supplement aggregate landings statistics such as those supplied to the Food and Agricultural Organization (FAO) with other data to understand better the dynamics of intensification, expansion, and stock depletion in coastal small-scale fisheries (Berkes et al. 2003, Pauly and Zeller 2003, Murray et al. 2006, 2008).

Fishers often possess a profound understanding of complex marine systems based on long-term interactions with their environment (Neis et al. 1999, Berkes et al. 2000). This accumulated knowledge, passed down through generations, is an important source of information about historical changes in local marine resources as well as social changes in marine social-ecological conditions (Johannes et al. 2000). In addition, fishers can provide critical information, particularly in data-poor situations, on changes in stock distribution and abundance as well as changes in fishing effort and fishing practices that are critical for interpreting catch-rate data (Haggan et al. 2007).

Here, we draw on case study research in coastal Mozambique that combines national landings with career-history interviews with fish harvesters to generate a multi-scale historical reconstruction that describes social-ecological interactions within the coastal fishery and provides insights into the utility

${ }^{1}$ University of Victoria, ${ }^{2}$ Vancouver Island University 
of combining these types of data. We begin by presenting our methodology. The results and discussion section is presented in two sections: macro-scale restructuring based on landings data (1950-2009) and micro-scale restructuring based on fishers' knowledge. We conclude with a discussion of the major trends and the implications of a multi-source data approach for fisheries governance.

\section{METHODS}

\section{Study site}

In 2009, with the assistance of local researchers from the University of Eduardo Mondlane's School of Coastal and Marine Science (UEM-ESCMC) and staff at the Institute for the Development of Small-Scale Fisheries (IDPPE), we selected Zalala Beach as our study site because of its location near the productive Sofala Bank and its long history of both small-scale and industrial fishing. Zalala is located $30 \mathrm{~km}$ north of Quelimane, on Mozambique's central coast (Fig. 1). Zalala has a multi-species fishery focused primarily on shallow-water shrimp (e.g., Acetes erythraeus) and pelagics such as sardines and anchovies. Fishers fish from dugout canoes or larger wooden lancha vessels that the government of Mozambique defines as small scale (Afonso 2006). Lanchas can accommodate crews of 20 fishers and are typically rowed or sailed. In 2009, there were two vessels with motors at Zalala Beach (A. Camunada, IDPPE, personal communication). Fishers primarily use gill nets, seine nets, and hand lines (IDPPE 2009). Catches landed at the beach are dried (24.6\%), salted (22.3\%), smoked (23.4\%), frozen (14.2\%), or sold fresh (15.5\%; IDPPE 2009). The majority of fishers at Zalala Beach speak Chuabo or Sena as their first language and Portuguese as their second. Access to central markets in Zalala is limited by poor roads and limited motorized vehicle transportation. The majority of fish are sold to markets in surrounding districts by middlemen (called compradores) or consumed by fishing households.

\section{Macro-scale data}

Landings data were retrieved from the FAO's FishStat Plus database (FAO 2011). They consist of total national marine capture production in Mozambique's exclusive economic zone between 1950 and 2009. Data include all quantities of fish, crustaceans, and molluscs caught and landed, but exclude discards, harvest from aquaculture and marine mammals, inland capture, sponges, and aquatic plants. Data on the number of small-scale fishers in Mozambique were retrieved from the IDPPE small-scale fishers' census (IDPPE 1998, 2004, 2009). Landings and fishers data were imported into, and graphed in, Microsoft Excel 2010. To describe sociopolitical, economic, and governance trends at the macro level over the last five decades, we consulted the peer-reviewed literature on fisheries in Mozambique and publications from the Ministry of Fisheries. We also reviewed the grey literature such as dissertations, technical papers, and project reports, which are an important source of information, particularly in Africa, where peer-reviewed publications are often limited (Jiddawi and Öhman 2002).

Fig. 1. Map of Mozambique (grey). The study site, Zalala Beach, is located $30 \mathrm{~km}$ north of Quelimane.

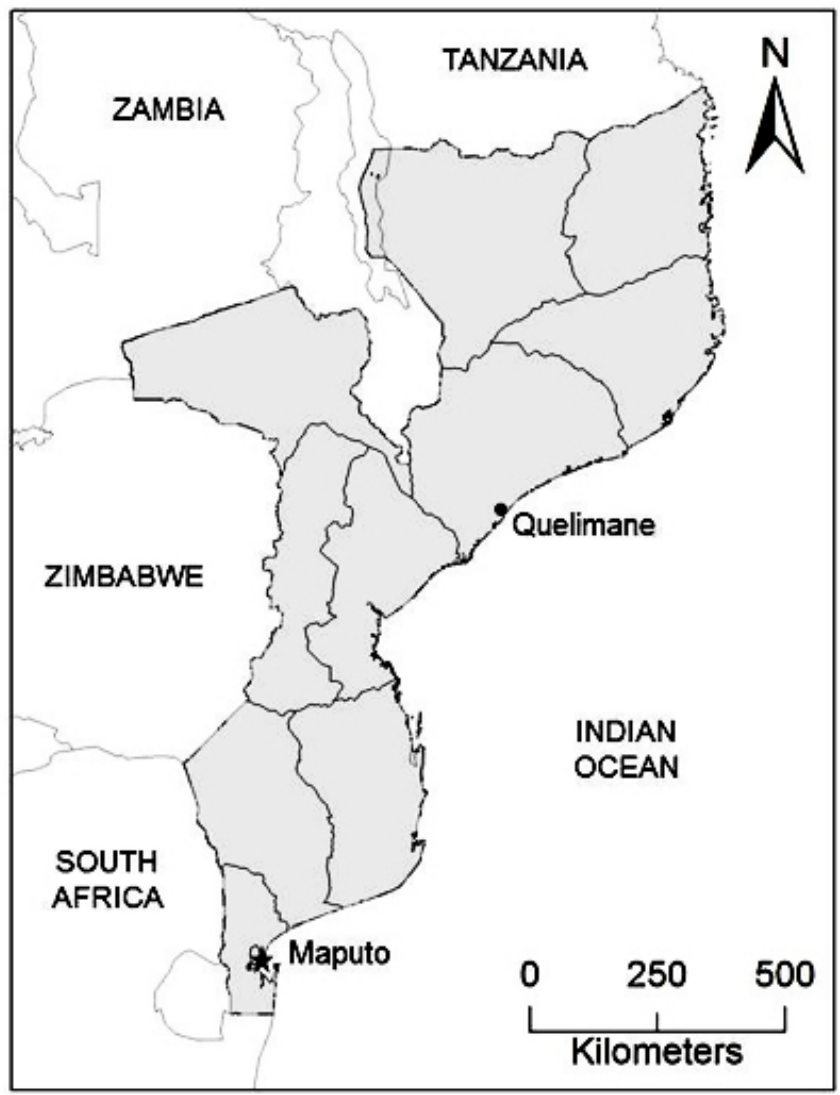

\section{Interviews}

To supplement landings and other macro-level data, we conducted semi-structured interviews, adapted for the study of fishing communities, with experienced fishers in Mozambique (McGoodwin 2001). Initial respondents were identified by the village head (Secretaria do Bairro) based on two criteria: (1) the fisher derived his/her livelihood primarily from fishing and (2) the fisher had a minimum of $10 \mathrm{yr}$ of fishing experience. Subsequent respondents were identified through snowball sampling by asking interviewees to suggest other experienced fishers at Zalala Beach (Davis and Wagner 2003). Interview questions were tested in a pilot study with students from UEM-ESCMC. We interviewed 15 fishers between September and December 2010 and 10 fishers between May and July 2012, which coincided deliberately with the high and low fishing seasons, respectively. The 
Fig. 2. (a) Periods of socioeconomic change affecting coastal fisheries (adapted from Menezes et al. 2011). (b) Total landings for 1950-2009 (FAO 2011) and total number of small-scale fishers (IDPPE 1998, 2004, 2009) in Mozambique.
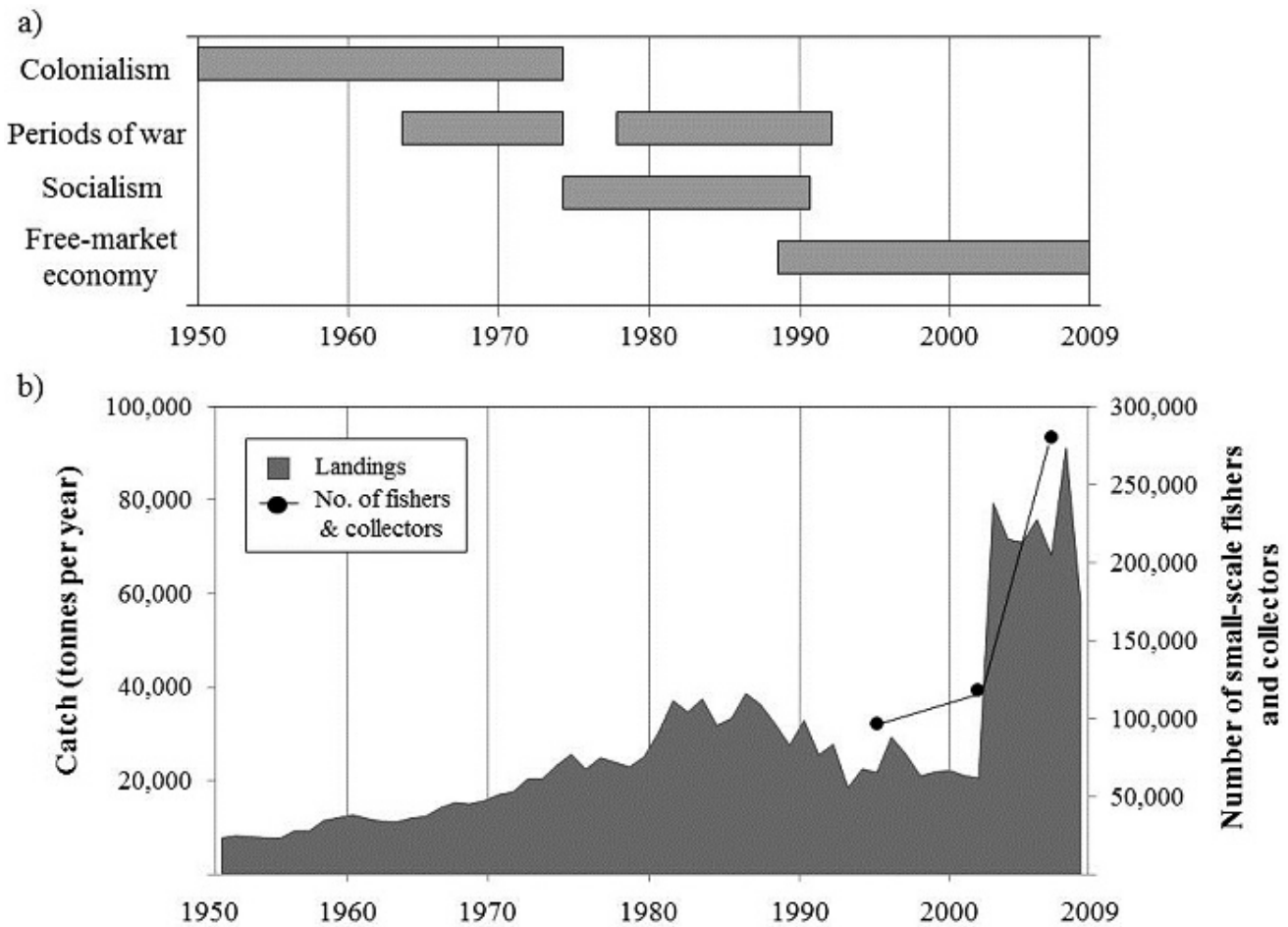

majority of interviews were conducted mid-morning, on the beach, as fishers returned from fishing. Interviews were conducted in Portuguese, Chuabo, or Sena, with translation assistance from a Masters student from UEM-ESCMC and an IDPPE extension agent. Fishers were asked to describe changes in fish abundance and distribution, physical environment, social and cultural context, regulatory changes, and fishing practices. Interviews typically lasted between 30 and $45 \mathrm{~min}$. Throughout the interviews, we also emphasized the drivers of the observed changes in an attempt to understand fishers' perceptions of and responses to change. For example, when discussing changing boat type, we focused on when this change occurred, why it occurred, and how it affected their catch. Interviews were coded using qualitative software (NVivo 9). Descriptive statistics (mean age, years fishing, and daily catch) were calculated using Microsoft Excel 2010.

\section{RESULTS AND DISCUSSION}

\section{Macro-scale restructuring in Mozambican fisheries: 1950-2009}

The last fifty years of Mozambique's history can be divided into four fairly distinct socioeconomic periods: colonialism, periods of war, socialism, and free-market economy. We relate the available national landings data to these four periods (Fig. 2).

In the 16th century, when the Portuguese arrived in Mozambique, an estimated 10,000 people were living along the Sofala bank and engaging in fishing (Ehnmark and Wästberg 1963). For the majority of the colonial period, fishing remained largely subsistence based because trawling was prohibited by colonial fishery law (Lopes and Gervásio 2003). In the early 1960s, however, the Portuguese began to recognize the export earning potential of a shrimp fishery (Jacquet and Zeller 2007). They overturned the trawling ban, established a small industrial fleet that was owned and operated by crews from Portugal, and built large processing and freezer plants along the coast (Menezes et al. 2011). During the colonial period, landings were not collected for the small-scale sector. However, it has been estimated that > 16,000 rural fishers were active along the coast (Herrick et al. 1969). From the 1950s until the mid-1970s, national landings rose gradually (Fig. 2).

Approximately $500 \mathrm{yr}$ of colonial rule came to a close when the Front for the Liberation of Mozambique (FRELIMO) 
initiated an armed campaign for independence in 1964. After a decade of conflict, which destroyed much of the country's infrastructure, FRELIMO established an independent socialist state. The new government nationalized and invested in the industrial fishery following the colonial war (Menezes et al. 2011). In 1976, Mozambique established a 200-mile exclusive economic zone. In need of foreign exchange, the government formed joint enterprises with private fishing interests in Japan, Spain, and Norway, and traded fishing rights for aid from the Soviet Union (Jacquet and Zeller 2007). Although Mozambique's fishing grounds had not been fully surveyed, Norway suggested increasing the annual production of fish by 20,000 tonnes by 1985 through the adoption of bottom trawling (Azevedo 2002). By the early 1980s, shrimp made up more than one-quarter of total national landings and became Mozambique's second largest earner of foreign exchange, cashews being the first (Jacquet and Zeller 2007, FAO 2011). Supported by these investments, industrial landings grew and peaked in the mid-1980s (Fig. 2). The new socialist government also invested in the small-scale fishery. They introduced fishing cooperatives (called combinados pesqueiros) in the early 1980s (Menezes et al. 2009). The cooperatives focused on meeting state production targets and supported the small-scale fishers by providing fishing gear, building processing facilities, and increasing access to central markets. This resulted in a new level of livelihood security in the small-scale sector (Menezes et al. 2011).

In 1977, a civil war erupted between the ruling socialist FRELIMO and the anti-communist Mozambique National Resistance (RENAMO), which led to mass migrations. Close to two million Mozambicans fled abroad while approximately four million people were displaced internally (Azevedo 2002). The majority of internally-displaced people fled from fighting in the interior to coastal areas (Menezes et al. 2009). Once along the coast, many refugees turned to fishing (Menezes 2008). Historical evidence suggests that the additional fishing pressure resulting from this migration led to declining landings during the civil war (Fig. 2; Lopes and Gervasio 1999, Menezes et al. 2011). During the civil war, little legislation was adopted for fisheries and resource monitoring was limited (Afonso 2006). In 1992, both parties signed a cease-fire agreement.

Toward the end of the civil war, the government began to transform the nation's centrally planned economy into a freemarket system. In 1987, Mozambique adopted the International Monetary Fund's structural adjustment programs. In November 1990, the Constitution and first Fisheries Act were established (Mozambique Ministry of Fisheries 1995). These economic and political shifts created significant reforms in the government's relationship with small-scale fisheries. For example, fishing cooperatives were abolished (Menezes 2008), government service shifted from direct intervention through the provision of services to the creation of local governance institutions (Menezes et al. 2009), and the government began promoting fisheries comanagement (Mozambique Ministry of Fisheries 1995). In addition, free-market reforms led to hardship in many fishing communities; schools and health centers were closed, and direct government assistance for small-scale fishers was reduced (Menezes et al. 2009, 2011). Landings fluctuated through the 1990s, but never returned to their 1980s levels (Fig. 2). Yet, since the end of the civil war, Mozambique has experienced steady economic growth. The government has begun to rebuild its resource-management capacity and allocated resources to improve monitoring of the small-scale fisheries sector (Afonso 2006).

Clearly something unusual happened in 2003 (Fig. 2). In that year, the government began reporting small-scale catch data to the FAO for the first time, and landings jumped from 20,515 tonnes in 2002 to 79,451 tonnes in 2003 (FAO 2011). These data indicate that small-scale fishers are catching $>75 \%$ of total national landings, which is very significant considering that data for the sector are only available since 2003. Fortunately, by combining estimates of individual catch rates and total number of small-scale fishers, Jacquet et al. (2010) reconstructed total marine catch for Mozambique between 1950 and 2005. While there is a level of uncertainty associated with their estimates, their reconstruction presents two important points. First, small-scale landings reported since 2003 were based on a sample of fishing centers and provinces, which were not extrapolated countrywide. Therefore, Jacquet et al. (2010) estimate that Mozambique's annual catch rates were potentially between 47,000 and 177,000 tonnes higher than the reported data suggest. Second, reconstructed marine catch data indicate that small-scale landings peaked in the mid-1980s followed by a subsequent decline, which suggests overfishing of local resources (Jacquet et al. 2010). Thus, data provided to the FAO suggest that small-scale landings in Mozambique account for three-quarters of total marine catch and that they have been significantly under-reported. Reconstructed catch data suggest that national landings have declined since the 1980s, yet the explanatory power of the reconstruction data is limited by minimal input data and a high level of uncertainty associated with estimates. Alone, the existing data for the coastal Mozambican fishery cannot address the diversity of changes in fish abundance or distribution, location-specific interactions of humans with physical environmental heterogeneity, the effects of new technologies on marine landings, and social, cultural, or regulatory change. It is, therefore, critical to identify other sources of information that can complement the data provided to the FAO and contribute to our understanding of the interactions between small-scale fishers and coastal marine resources. 
Table 1. Common observations of change as described by fishers at Zalala Beach. $\dagger$

\begin{tabular}{ll}
\hline \hline Themes & Common observations \\
\hline Changes in fish distribution and abundance & Declining stocks \\
& Reduced abundance of all species in inshore waters \\
Physical environmental changes & Unpredictable rains \\
Social and cultural changes & Increasing storm frequency and severity \\
Regulatory changes & Increasing number of fishers \\
& Abandonment of traditional cultural practices \\
& IDPPE extension \\
Changes in fishing techniques & Closed season \\
& Banning of mosquito nets \\
& Increasing boat length and power \\
& Increasing net size or changing net type \\
& Fishing in the open ocean \\
\hline
\end{tabular}

$\dagger N=25$.

$\ddagger$ Institute for the Development of Small-Scale Fisheries.

\section{Micro-scale restructuring: fishers' knowledge}

During the last few decades, fishers along Mozambique's coast have witnessed, participated in, and responded to radical transformation within their social-ecological system. We next present fishers' descriptions of change in the fishery along the Sofala Bank (Table 1).

\section{Changes in fish abundance and distribution}

Fishers $(N=25$; mean age $=42 \mathrm{yr} \pm 12.44$ [SD]; mean years fishing $=14 \mathrm{yr} \pm 7.41[\mathrm{SD}]$ ) have observed significant declines in marine stocks at Zalala Beach. They noted that both shallowwater prawns and small pelagics, the most important subsistence resources for the community, are less numerous than they were during the previous few decades. In the late $1990 \mathrm{~s}$, fishers reported catching an average of $2525 \mathrm{~kg} \mathrm{day}^{-1}$ lancha-boat $^{-1}$ of fish between November and February, the high season on the Sofala Bank (Table 2). Today, fishers report that their daily catch, during the high season, has declined to an average of $1095 \mathrm{~kg} \mathrm{day}^{-1}$ lancha-boat ${ }^{-1}$. These catch-perunit-effort data complement some of the qualitative data obtained during the interviews. For example, one fisher observed, "When I started fishing [16 yr ago], there were many fish. With only one launch, we would catch enough fish that we wouldn't have to continue fishing that day. Now, this is no longer the case. It takes many trips, and we catch only a little fish."

In addition to declining catches, the spatial distribution and body size of the targeted species has changed. Fewer and smaller fish are caught in the inshore waters. One respondent noted, "I have to travel further to catch the fish I want to with my [seine] net. Here, along the edge of the beach, you don't catch big fish anymore. To catch big fish you need to go to the open ocean with a gill net."
Table 2. Average reported daily catch/lancha-boat $(\mathrm{kg})$ at Zalala Beach. $\dagger$

\begin{tabular}{lll}
\hline \hline & $\begin{array}{l}\text { High season } \\
\text { (November to } \\
\text { February) }\end{array}$ & $\begin{array}{l}\text { Low season } \\
\text { (June to August) }\end{array}$ \\
\hline Current & $1095.0 \pm 309.5$ & $136.0 \pm 92.5$ \\
Historical $(15 \mathrm{yr}$ ago) & $2525.0 \pm 1762.5$ & $177.5 \pm 132.6$ \\
\hline$\dagger N=10$. & & \\
& & \\
\hline
\end{tabular}

Fishers identified changes in the physical environment, along with socioeconomic and cultural changes, as the primary drivers of the observed changes in fish abundance and distribution.

\section{Physical environmental changes}

Fishers perceived the nature and timing of seasonal rains to be different now than they have been in the past. Their perception is supported by data showing that the frequency of both droughts and flooding has increased in Mozambique during the last decade (Artur and Hilhorst 2012). One fisher explained, "Now the weather is changing a lot. In October/ November it no longer rains. Therefore, we' re not catching as many fish." Seasonal precipitation is critical for marine productivity (Hoguange et al. 2012), and fishers at Zalala Beach clearly understand this relationship. One informant explained, "When rain doesn't fall, the fish disappear. When it rains, there are lots of fish, and we catch lots of fish." Because of the correlation between rainfall and fish productivity, 
fishing communities are highly sensitive to changes in precipitation.

In addition to the unpredictable nature of rainfall, informants described increasing frequency and severity of coastal storms. For example, one informant stated, "The water is always agitated, there are stronger currents, and storms never stop." Storms can have severe effects on rural fishing communities. Small-scale, man-powered vessels are ill equipped for storms at sea. Storms damage homes (typically made with mud walls and grass roofs), fishing gear, and machambas (local term for subsistence gardens). In the most extreme cases, storms result in the loss of life. In 2010, several weeks before our interviews, a boat with 20 fishers was lost during a storm off Zalala Beach. The head of one of the fishers' associations explained, "Storms increase the number of deaths among fishers. This leaves a large number of orphaned children and widows behind."

\section{Social and cultural changes}

Fishers also described a range of social and cultural changes, including a rapid rate of in-migration and cultural shifts related to fishers' spiritual relationship with the sea. Informants consistently reported that the number of fishers at Zalala has been rising for years. Word has spread about good fishing conditions and an abundance of fish buyers at Zalala. With work becoming scarcer inland and other fishing areas becoming increasingly overexploited, fishers from other districts and provinces have migrated to Zalala Beach. One fisher explained, "The fishery was better before now. When immigrants came from Pebane, Moma, and Angoche, the amount of fish decreased." Often, full crews of fishers arrive from other districts and do not permit local fishers to join them. In a few cases, this has led to conflict between local and immigrant fishers. However, the most significant effect of the increasing number of fishers is the reduced total quantity of fish. In addition to migrants from other areas, local residents are also turning to fishing. One informant noted, "I've seen the number of fishermen increase and the number of fish decrease. Today, people who have never dreamed of becoming a fisher are fishing, and they all like to fish in the same area. So, how can there be many fish left in the sea?"

Older respondents described cultural changes occurring at Zalala Beach. They explained that some of the younger fishers have lost their fear of the ocean and a respect for fishing traditions. When we asked what is driving the changes in the fishery, one respondent remarked, "The development of the world. A long time ago, no one slept in the open ocean because there was a spirit there and people were afraid. But today, with development, no one is afraid; they go to the open ocean, cook there, and sleep there, and the spirit has gone."

Older fishers believe that their ancestors control the marine resources; they hold ceremonies at the beginning of each fishing season to ask the ancestors for good fishing conditions. They interpret the decline in fish stocks as a sign of ancestral anger, which the community has provoked because it has largely stopped holding these traditional ceremonies.

\section{Regulatory changes}

Fishing regulations at Zalala Beach have gone through several transformations during the last two decades. Since the early 1990s, the IDPPE (Institute for the Development of SmallScale Fisheries) has been sending extension agents to Zalala Beach. The agents work with fishers on methods for improving catch rates (by increasing access to gill nets and motors), catch preservation (through salting and drying), and safety (through the introduction of life jackets). By the early 2000s, extension programs also focused on establishing saving and lending groups (called poupança e crédito rotativo, or PCR) and community fishing councils (called conselho comunitário de pesca, or (CP) who enforce fishing regulations and facilitate PCRs. Some respondents indicated that these programs have helped them to increase their catch and improve their preservation techniques. Others believe that the assistance has led to more efficient fishing and thus a decline in the fishery. One respondent explained, "Now, there's a lot of money in the district, and we can get financing for buying fishing nets; therefore, the number of fish is going down. We are many fishers, and there's not enough fish for everyone."

In 2000, Mozambique's government imposed an annual closed season for the small-scale fishery from December to March. It also assisted in the development of fishers associations (CCP) who, among other things, help to enforce the closed season. Many fishers described how the closed season is a very difficult time for them because they cannot generate daily income from the fishery, and hunger becomes prevalent in much of the community. However, respondents also explained that over a longer period, the closed season is important for the health of the fishery. One fisher observed, "There didn't used to be a closed season. Now there is a closed season, during which there is only a little fishing. The closed season allows the fish to reproduce."

In 2000, the government also banned fishing with mosquito nets because of their detrimental effects on larval fish populations. Before this regulation was introduced, the bags at the end of seine nets were commonly made of mosquito netting. Currently, the regulated mesh size is $2.5 \mathrm{~cm}$, or as one fisher put it, "two fingers width," although slightly smaller mesh is permitted in certain districts. For the most part, fishers at Zalala Beach agree with the mesh size regulation and comply with it (H. Manjor, IDPPE, personal communication).

\section{Changes in fishing techniques}

Fishers at Zalala Beach have had to adapt their practices in response to changes in fish distribution and abundance. Prior to the 2000s, the majority of them fished from traditional, rowed dugout canoes. Today, most of them use larger wooden lancha boats (Fig. 3). Lancha boats are typically rowed or sailed, but increasingly fishers are acquiring motors to power 
these boats, with the motors acquired through small loans. In addition to increasing vessel size, many fishers are changing from beach seine nets to gill nets, giving them access to previously inaccessible fishing grounds. One fisher explained, "Boats used to be of medium size (6-7 m). Now boats are 9$10 \mathrm{~m}$, and we fish with gill nets that can go deep in the open ocean. In the past, we didn't have these things."

Fig. 3. A lancha boat (foreground) and its smaller predecessor, a traditional dugout canoe (background) at Zalala Beach, Mozambique. (Photo: J. Blythe).

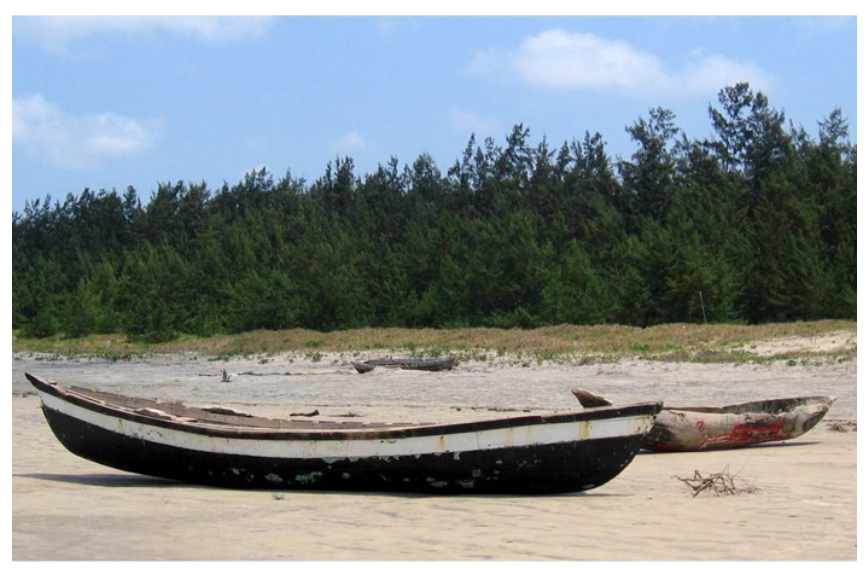

Historically, fishers at Zalala Beach fished the inshore waters using beach seines. In response to decreasing inshore catch during the last decade, they have begun to travel further offshore in search of desirable catch. Fishers also described a decrease in their catch per unit effort. Respondents explained that they now make multiple and longer trips to catch the same quantity of fish that they used to catch in a single trip. One respondent observed, "Historically, fishers didn't sleep at sea, but now they sleep at sea to see if they can catch fish during the night." Another noted, "When I first started fishing, we used to catch a lot of fish, not like today when we only catch a little. After one trip, you wouldn't have to fish any more. Today, we need three or four trips to earn enough money."

Respondents are well aware of the effects of increasing their fishing intensity on marine resources. One fisher explained, "The lack of fish is due to us changing our type of boats, so now we can travel further into the open ocean and catch more fish."

\section{CONCLUSION}

Our macro- and micro-level data provide clear evidence of the small-scale fishery's impact on marine resources in Mozambique. At the macro-level, our findings corroborate other historical reconstructions that suggest that the smallscale sector is responsible for up to three-quarters of national landings (Jacquet et al. 2010). National landings rose through the 1960s and 1970s as Portuguese colonials began to invest in an industrial shrimp industry. During the civil war, mass migrations to the coast placed additional pressure on the smallscale fishery. At the same time, the newly independent government formed joint enterprises with international partners, adding additional pressure to the fishery. In 2003, Mozambique began reporting small-scale landings to the FAO for the first time, and landings jumped from 20,000 tonnes to almost 80,000 tonnes, demonstrating the huge impact of the small-scale sector on total national landings.

At the micro-level, fishers indicate that the inshore, shallow waters are depleted and that fish length is decreasing, trends that have been documented elsewhere in Mozambique (de Boer et al. 2001) and in Africa (Atta-Mills et al. 2004). In addition, fishers at Zalala Beach report declining catch per unit effort. In southern Mozambique, de Boer et al. (2001) documented a similar decline. In contrast to claims that limited technology, poor infrastructure, and weak capacity minimize the effects of small-scale fisheries (Menezes et al. 2011), we add our voice to the growing group of scholars who argue that small-scale fisheries can, under certain conditions, lead to overexploitation of marine resources (see also AlfaroShigueto et al. 2010, Jacquet et al. 2010).

By drawing on data from multiple sources and scales, we have been able to gain new insights into the drivers of socialecological restructuring in coastal Mozambique. At the national scale, landings data point to peak catches in the mid-1980s and a subsequent decline, suggesting that national fisheries are overexploited. At the local scale, fishers' experiences substantiate macro-scale trends of overexploitation and highlight social, biophysical, and cultural drivers of change. Fishers identify increasing fishing pressure as the primary cause of declining catches, and their observations are supported by government census data (IDPPE 1998, 2004 2009). This trend is evident in other poor coastal countries, where the small-scale fishery offers a relatively accessible form of employment and where fishery regulations are few and/or poorly enforced (Alfaro-Shigueto et al. 2010). Fishers explained that the lack of rain during the past few years has led to reduced marine productivity, a relationship that has also been identified by natural scientists in Mozambique (Hoguange et al. 2012). Fishers at Zalala also link declining marine productivity with the loss of traditional ceremonies to honor their ancestors, which have guided the rules of conduct at sea for generations. This loss of traditional culture has also been documented in fishing communities in Kenya (McClanahan 1997), suggesting a wider trend of declining traditional management of natural resources along the east African coast. These nuanced descriptions of social-ecological drivers of change are not possible to identify through landings data alone. An important direction for future research is to evaluate the relative importance of these multiple drivers of change in coastal systems. 
Fisheries are dynamic social-ecological systems characterized by change and variability. Fishers at Zalala Beach understand that multiple factors are driving changes in marine fish stocks, and they have responded by employing an equally varied set of adaptation strategies. Fishers' behaviors are motivated by multiple, interacting forces ranging from the biophysical to the cultural. It is critical that fisheries policies be sensitive to how fishers experience and respond to change, and it is insufficient to try to discern these complexities from a single source of data. For example, over the last $15 \mathrm{yr}$, fishers at Zalala Beach have transitioned to bigger boats and bigger nets in response to increasing scarcity of inshore fish (ecological driver of change), but also in response to increasing access to government loans (political/economic driver of change). Further, in response to declining catches, fishers are making more trips per day and spending the night fishing at sea, which historically did not occur at Zalala. These modifications are logical responses to changes in marine stocks and fisheries regulations. Night trawls in Mozambique, for example, yield significantly larger catches than do day trawls (de Boer et al. 2001). Fishers' responses are reflective of broader trends of intensification and spatial expansion in small-scale fisheries (McClanahan et al. 1997, Sabetian and Foale 2006). Their responses illustrate the iterative relationships between biophysical and social components of a social-ecological system.

Historical reconstructions of fisheries are essential for understanding and managing contemporary coastal systems (Ommer 2007, Murray et al. 2007). This is particularly true in Mozambique, where landings data are recognized as incomplete (Jacquet et al. 2010) and "nothing is known about fishing pressure in the past" (de Boer et al. 2001:226). We suggest that historical reconstructions based on data of multiple types and scales will more effectively capture the complexities that characterize interactions among fish, fishers, and their social-ecological context than any single type of data.

Responses to this article can be read online at: http://www.ecologyandsociety.org/issues/responses. $\mathrm{php} / 5759$

\section{Acknowledgments:}

The financial support of the Canadian International Development Agency (CIDA, project number S61268-652) and the Social Sciences and Humanities Research Council of Canada (SSHRC CGS) is gratefully acknowledged. Funding was also provided by the Centre of International Governance Innovation's Africa Initiative exchange program. We are indebted to the University of Eduardo Mondlane's School for
Coastal and Marine Science and the Institute for the Development of Small-Scale Fisheries in Quelimane, Mozambique, for support during our fieldwork. This paper benefited from comments from Rosemary Ommer and Barbara Patterson. Finally, this work would not have been possible without the generosity of the fishers at Zalala Beach who shared their time and experiences with us.

\section{LITERATURE CITED}

Afonso, P. S. 2006. Country review: Mozambique. Pages 415-423 in C. De Young, editor. Review of the state of the world marine capture fisheries management: Indian Ocean. FAO Technical Paper 488. Food and Agriculture Organization, Rome, Italy. [online] URL: http://www.fao.org/ docrep/009/a0477e/a0477e00.HTM\#Contents.

Alfaro-Shigueto, J., J. C. Mangel, M. Pajuelo, P. H. Dutton, J. A. Seminoff, and B. J. Godley. 2010. Where small can have a large impact: structure and characterization of small-scale fisheries in Peru. Fisheries Research 106(1):8-17. http://dx. doi.org/10.1016/j.fishres.2010.06.004

Artur, L., and D. Hilhorst. 2012. Everyday realities of climate change adaptation in Mozambique. Global Environmental Change 22(2):529-536. http://dx.doi.org/10.1016/j. gloenvcha.2011.11.013

Atta-Mills, J., J. Alder, and U. R. Sumaila. 2004. The decline of a regional fishing nation: the case of Ghana and West Africa. Natural Resources Forum 28(1)13-21. http://dx.doi. org/10.1111/j.0165-0203.2004.00068.X

Azevedo, M. J. 2002. Tragedy and triumph: Mozambique refugees in southern Africa, 1977-2001. Heinemann, Portsmouth, New Hampshire, USA.

Béné, C. 2003. When fishery rhymes with poverty: a first step beyond the old paradigm on poverty in small-scale fisheries. World Development 31(6):949-975. http://dx.doi.org/10.1016/ S0305-750X(03)00045-7

Berkes, F., J. Colding, and C. Folke. 2000. Rediscovery of traditional ecological knowledge as adaptive management. Ecological Applications 10(5):1251-1262. http://dx.doi. org/10.1890/1051-0761(2000)010[1251:ROTEKA]2.0.CO;2

Berkes, F., J. Colding, and C. Folke, editors. 2003. Navigating social-ecological systems: building resilience for complexity and change. Cambridge University Press, Cambridge, UK. http://dx.doi.org/10.1017/CBO9780511541957

Davis, A., and J. R. Wagner. 2003. Who knows? On the importance of identifying "experts" when researching local ecological knowledge. Human Ecology 31(3):463-489. http:// dx.doi.org/10.1023/A:1025075923297 
de Boer, W. F., A. M. P. van Schie, D. F. Jocene, A. B. P. Mabote, and A. Guissamulo. 2001. The impact of artisanal fishery on a tropical intertidal benthic fish community. Environmental Biology of Fishes 61(2):213-229. http://dx.doi. org/10.1023/A:1011043510100

Ehnmark, A., and P. Wästberg. 1963. Angola and Mozambique: the case against Portugal. Pall Mall Press, London, UK.

FAO. 2011. FishStat Plus: capture production 1950-2011. Food and Agriculture Organization, Rome, Italy. [online] URL: http://www.fao.org/fishery/statistics/software/fishstat/ en.

Garcia, S. M., and I. de Leiva Moerno. 2003. Global overview of marine fisheries. Pages 1-24 in M. Sinclair and G. Valdimarsson, editors. Responsible fisheries in the marine ecosystem. CABI, Wallingford, UK.

Haggan, N., B. Neis, and I. G. Baird, editors. 2007. Fishers' knowledge in fisheries science and management. United Nations Educational, Scientific and Cultural Organization, Paris, France. [online] URL: http://portal.unesco.org/science/ en/files/5199/11744843521Fishers-Knowledge-sections2007. pdf/Fishers-Knowledge-sections2007.pdf.

Herrick, A. B., A. Bastos, F. R. Eilsele, S. A. Harrison, H. J. John, and T. K. Wieland. 1969. Area handbook for Mozambique. U.S. Government Printing Office, Washington, D.C., USA.

Hoguange, A. M., E. da Lucia Cuamba, and T. Gammelsrød. 2012. Influence of rainfall on tropical coastal artisanal fisheries - a case study of northern Mozambique. Journal of Integrated Coastal Zone Management 12(4):477-482.

IDPPE. 1998. Censo nacional da pesca artesanal aguas maritimas. Instituto de Desenvolvimento de Pesca de Pequena Escala, Maputo, Mozambique.

IDPPE. 2004. Censo nacional da pesca artesanal aguas maritimas. Instituto de Desenvolvimento de Pesca de Pequena Escala, Maputo, Mozambique.

IDPPE. 2009. Recenseamento da pesca artesanal 2007. Instituto de Desenvolvimento de Pesca de Pequena Escala, Maputo, Mozambique.

Jackson, J. B. C., M. X. Kirby, W. H. Berger, K. A. Bjorndal, L. W. Botsford, B. J. Bourque, R. H. Bradbury, R. Cooke, J. Erlandson, J. A. Estes, T. P. Hughes, S. Kidwell, C. B. Lange, H. S. Lenihan, J. M. Pandolfi, C. H. Peterson, R. S. Steneck, M. J. Tegner, and R. R. Warner. 2001. Historical overfishing and the recent collapse of coastal ecosystems. Science 293:629-638. http://dx.doi.org/10.1126/science.1059199

Jacquet, J. L., H. Fox, H. Motta, A. Ngusaru, and D. Zeller. 2010. Few data but many fish: marine small-scale fisheries catches for Mozambique and Tanzania. African Journal of Marine Science 32(2):197-206. http://dx.doi.org/10.2989/1814232X.2010.501559

Jacquet, J. L., and D. Zeller. 2007. National conflict and fisheries: reconstructing marine fisheries catches for Mozambique. Pages 35-47 in D. Zeller and D. Pauly, editors. Reconstruction of marine fisheries catches by countries and regions (1950-2005). Fisheries Centre Research Report 15(2). University of British Columbia, Vancouver, Canada.

Jiddawi, N. S., and M. C. Öhman. 2002. Marine fisheries in Tanzania. Ambio 31(7-8):518-527. DOI: http://dx.doi. org/10.1579/0044-7447-31.7.518

Johannes, R. E., M. M. R. Freeman, and R. J. Hamilton. 2000. Ignore fishers' knowledge and miss the boat. Fish and Fisheries 1(3):257-271. http://dx.doi.org/10.1111/ j.1467-2979.2000.00019.x

Lopes, S., and H. Gervásio. 1999. Co-management of smallscale fisheries in Mozambique: a case study of Kwirikwidge fishing community in Angoche District, Nampula Province. International Workshop on Fisheries Co-Management, Penang, Malaysia. [online] URL: http://www.oceandocs.net/ bitstream/1834/752/1/lopes2003.pdf.

Ludwig, D., R. Hilborn, and C. Walters. 1993. Uncertainty, resource exploitation, and conservation: lessons from history. Science 260:17-36. http://dx.doi.org/10.1126/science.260.5104.17

McClanahan, T. R., H. Glaesel, J. Rubens, and R. Kiambo. 1997. The effects of traditional fisheries management on fisheries yields and the coral-reef ecosystems of southern Kenya. Environmental Conservation 24(2):105-120. http:// dx.doi.org/10.1017/S0376892997000179

McGoodwin, J. R. 2001. Understanding the cultures of fishing communities: a key to fisheries management and food security. FAO Technical Paper 401. Food and Agriculture Organization, Rome, Italy. [online] URL: http://www.fao.org/ docrep/004/y1290e/y1290e00.htm.

Menezes, A. M. 2008. The governance of natural resources in Mozambique: artisanal fishery. Dissertation. State University of New York, Syracuse, New York, USA.

Menezes, A., A. Eide, and J. Raakjaer. 2011. Moving out of poverty: conditions for wealth creation in small-scale fisheries in Mozambique. Pages 407-425 in S. Jentoff and A. Eide, editors. Poverty mosaics: realities and prospects in smallscale fisheries. Springer, Dordrecht, the Netherlands. http:// dx.doi.org/10.1007/978-94-007-1582-0_18

Menezes, A., R. Smardon, and T. de Almeida. 2009. The changing dynamics of local institutions in fishing communities in Mozambique: responses to policy-public participation and decision making. Environmental Practice 11 (1):32-51. http://dx.doi.org/10.1017/S1466046609090085 
Mozambique Ministry of Fisheries. 1995. Fisheries master plan. Direcçao Nacional de Administracao Pesqueira, Maputo, Mozambique.

Murray, G., B. Neis, and J. P. Johnsen. 2006. Lessons learned from reconstructing interactions between local ecological knowledge, fisheries science, and fisheries management in the commercial fisheries of Newfoundland and Labrador, Canada. Human Ecology 34(4):549-571. http://dx.doi.org/10.1007/ s10745-006-9010-8

Murray, G., B. Neis, and D. C. Schneider. 2007. Lessons from a multi-scale historical reconstruction of Newfoundland and Labrador fisheries. Coastal Management 36(1):81-108. http:// dx.doi.org/10.1080/08920750701682056

Myers, R. A., and B. Worm. 2003. Rapid worldwide depletion of predatory fish communities. Nature 423:280-283. http://dx. doi.org/10.1038/nature01610

Neis, B., D. C. Schneider, L. Felt, R. L. Haedrich, J. Fischer, and J. A. Hutchings. 1999. Fisheries assessment: What can be learned from interviewing resource users? Canadian Journal of Fisheries and Aquatic Sciences 56(10):1949-1963. http:// dx.doi.org/10.1139/f99-115

Ommer, R. E. 2007. Coasts under stress: restructuring and social-ecological health. McGill-Queen's University Press, Montreal and Kingston, Canada.

Pauly, D., V. Christensen, J. Dalsgaard, R. Froese, and F. Torres, Jr. 1998. Fishing down marine food webs. Science 279:860-863. http://dx.doi.org/10.1126/science.279.5352.860

Pauly, D., and D. Zeller. 2003. The global fisheries crisis as a rationale for improving the FAO's database of fisheries statistics. Fisheries Centre Research Reports 11(6):1-9. [online] URL: http://www.seaaroundus.org/report/CAtrends/1PaulyZeller.pdf.

Sabetian, A., and S. Foale. 2006. Evolution of the artisanal fisher: case studies from Solomon Islands and Papua New Guinea. Traditional Marine Resource Management and Knowledge Information Bulletin 20:3-10. [online] URL: http://www.spc.int/DigitalLibrary/Doc/FAME/InfoBull/TRAD/20/ TRAD20 03 Sabetian.pdf.

St. Martin, K., B. J. McCay, G. D. Murray, T. R. Johnson, and B. Oles. 2007. Communities, knowledge and fisheries of the future. International Journal on Global Environmental Issues 7(2/3):221-239. http://dx.doi.org/10.1504/IJGENVI.2007.013575

Zeller, D., S. Booth, P. Craig, and D. Pauly. 2006. Reconstruction of coral reef fisheries catches in American Samoa, 1950-2002. Coral Reefs 25:144-152. http://dx.doi. org/10.1007/s00338-005-0067-4
Zeller, D., S. Booth, G. Davis, and D. Pauly. 2007. Reestimation of small-scale fisheries catches for the U.S. flagassociated island areas in the western Pacific: the last 50 years. Fishery Bulletin 105(2):266-277. 